\title{
The Influence of Individual Spirituality Toward Spirit at Work in Enhancing Organizational Commitment and Job Satisfaction
}

\author{
Amelia Naim Indrajaya ${ }^{1^{*}}$ \\ ${ }^{1}$ Sekolah Tinggi Manajemen Ipmi, Jakarta 12750, Indonesia
}

\begin{abstract}
A B S T RACT
The low spirit, lack of higher purpose and meaning in the workplace has an impact towards employees' morale. Eventually, the commitment to moral will decrease employees' productivity and organizational commitment at work. Therefore, this study aims to investigate the influence of individual spirituality toward spirit at work and how it enhances job satisfaction and organizational commitment. The quantitative research through questionnaires was conducted in the branch office of PT. Telkom with the highest revenue in the Central of Jakarta. The findings show the importance of workplace spirituality in enhancing job satisfaction and organizational commitments as important factors in increasing company's performance. Despite the growing belief that workplace spirituality significantly relates to performance, the evidence is still needed based on academically proven empirical research that great spirituality is part of the strategic management approach toward better performance. Furthermore, this study supported the hypotheses that individual spirituality is positively impacting spirit at work and in turn positively enhancing job satisfaction and organizational commitment. Further quantitative explanatory approach and/or qualitative exploratory approach will be needed to reach a more solid conclusion.
\end{abstract}

\section{ART I CLE IN F O}

Keywords:

Workplace spirituality, Strategic management, Individual spirituality, Organizational commitment, Job satisfaction
*Correspondent Email: amelia.naim@ipmi.ac.id permits unrestricted use, distribution, and reproduction in any medium, provided the original work is properly cited.

\section{INTRODUCTION}

Future organizations will require moral obligations of every organization to contribute to the solutions of the world problems in terms of the social gaps and environmental sustainability. Researchers have discovered that the spiritual sides of the organization are important issues in the company to encourage employees to see work as a part of a higher purpose and be part of the solution to the problems which are addressed by the Sustainable Developmental Goals of the United Nation (Mitroff \& Denton, 1999). 
This positive organizational purpose will motivate employees to work not only for the profit but for the people and the planet. Mitroff and Denton (1999), reported that organizations which perceived themselves as "more spiritual" also saw their organizations as giving more meaning and purpose to the employees, and at the end "more profitable" (better than their less spiritual counterparts). Looking at the organization as part of an interconnection for a higher purpose is one of the organizational level aspects of workplace spirituality .

Harvard Business School examined ten companies with high spiritual at work and ten companies with weak corporate cultures from a list of 207 leading corporations. The result of the research shows that in eleven years of longitudinal research there is a dramatic correlation between the companies with the high spirit culture to its profitability. In some of the cases, companies with high spiritual culture have outperformed the others in terms of net earnings, return on investment and shareholder value by 400 to 500 percent (Garcia-Zamor, 2003). Despite its growing popularity, currently, there is only limited research in regards to workplace spirituality as a dependent variable.

In this study, the researcher is looking to fulfill the gap and see the impact of individual spiritual quotient toward the spirituality at work (Spiritual at Work = SAW) or also called workplace spirituality, and to evaluate the impact of SAW toward organizational commitment and job satisfaction.

\section{LITERATURE REVIEW}

\section{Individual Spirituality (IS)}

The spirituality of the individual is derived from the work of Rojas and Argosy (2002). The construct is defined as a way to integrate an ideology of spiritual subjects, into an alternative human developmental process in everyday activities. The construct consists of thirteen relational modes of independent variables. The variables are confirming arrangements of personal behaviors selected as a response to a contextual, relational demand.
There are three specific behaviors for each relational mode. Four of the statements are purposefully reversed. The behaviors are operationalized into statements indicators and are subject to item validation through panels of experts and then subject to reliability and validity tests. Rojas (2002) completed this instrument and call it the Independent Spirituality Assessment Scale (ISAS).

\section{Spiritual at Work (SAW)}

Kinjerski and Skrypnek (2004), started by collecting all experts' research to develop a comprehensive, conceptual definition of SAW. Various scholars had conducted similar research on the topic called the workplace spirituality or spirituality at work. Based on other research on the topic, Kinjerski tried to develop a clear definition. Kinjerski then defined the rich similar descriptions of spirituality at work as (V.Kinjerski, 2004,p. 37):

"Spirit at work is a distinct state that is characterized by physical, affective, cognitive, interpersonal, spiritual and mystical dimensions. Most individuals describe the experience as including: A physical sensation characterized by a positive state of arousal or energy; characterized by a profound feeling of well-being and joy; cognitive features involving a sense of being authentic, an awareness of alignment between one's values and beliefs and one's work, and a belief that one is engaged in meaningful work that has a higher purpose; an interpersonal dimension characterized by a sense of connection to others and common purpose; a spiritual presence characterized by a sense of connection to something larger than self; and a mystical dimension characterized by a sense of perfection, transcendence, living in the moment, and experiences that were awe-inspiring, mysterious, or sacred.

This research-based definition is consistent with the definitions by other scholars Mitroff \& Denton (1999), Ashmos \& Duchon (2000), Millimen (2003) and Duchon \& Plowman (2005). In addition, it also covers the individual experiences in a spiritual workplace. It is also confirmed by research on confirming who experienced spirituality at work where the respondents are not familiar with the 
concept of workplace spirituality (V. M. Kinjerski \& Skrypnek, 2004).

\section{The Impact of Spiritual at Work Toward Organizational Commitment (OC) and Job Satisfaction}

The model in the research is also extended toward the impact of spiritual at work toward organizational commitment. In order to measure the impact of spirituality at work in an organization, experts have conducted researches of spirituality at work and its impact toward organizational commitment. Organizational commitment is the construct which shows the psychological state that characterizes the relationship between the employees' and its organization. Eventually, it will determine the likelihood whether the employees will stay in the company or leave it (Allen \& Meyer, 1990), (Meyer \& Parfyonova, 2010).

This construct has become one of the most cited models (Arménio \& Miguel Pina e, 2008). If employees feel that the organizations are treating them fairly, respectfully and in a supportive manner, they will be committed (Mitroff \& Denton, 1999). The organizational commitment itself is seen from different angles, namely affective, normative and continuance (Allen \& Meyer, 1990), with affective being the highest bonding of organizational commitment. The other dimensions are normative and continuance, with continuance being a bonding of organizational commitment for the purpose of continuance rather than affection.

There is many research looking at the impact of organizational commitment toward performance of organizations and the research had shown that there are significant positive relationship of organizational commitment toward organizational performance (Allen \& Meyer, 1990), (Riketta, 2002), (Hayati \& Caniago, 2012), (Grunberg, Anderson-Connolly, \& Greenberg, 2000), (Chen, Silverthorne, \& Hung, 2006), (Samad, 2005), (Memari, Mahdieh, \& Marnani, 2013).

There is an alternative research that shows $\mathrm{OC}$ has a negative impact toward performance (Wright, 1997). In this research, Wright is using data from 41 long-term employees. He observed that this finding is different from the others, possibly due to the long years of tenure of the respondents. Even though the respondents are highly committed, they might have reached the point of saturation and declining work ability. The major finding in this field of research is that the organizational commitment has a positive relationship with performance.

Soetjipto (2014), mentioned that there are many positive findings of the relationship between organizational commitment to performance that organizational commitment can be sufficient as a proxy to organizational performance in an organizational behavior research. Furthermore, in this research, the focus is on individual behaviors and not toward the organization as the unit analysis. Therefore in this research, we will use organizational commitment as the final findings with a positive understanding that it has a significant positive impact on organizational performance.

In addition to organizational commitment, this research will also measure the impact of spiritual at work toward job satisfaction. This is a very popular measurement that Mishra (2003) has mentioned. By 1991 there are over 12400 job satisfaction studies conducted only in the psychological literature. The study of job satisfaction is more prominent, as it is a central variable in many theories correlated directly with organizational performance. The study refers to numerous attitudes that employees have about their jobs, how they feel about their jobs in the general settings as well as various aspects of them. Unlike the measurement of productivity, absenteeism and other forms of measurement, job satisfaction as a measurement is only in the mind of the employees and cannot be measured directly. Researchers have conducted surveys with questionnaires since observations and interviews are too timeconsuming.

In this research, the popular measurement of Minnessota Satisfaction Questionnaire is adapted and used to measure job satisfaction. This questionnaire was developed since 1967 by Weis 
There are two types of questionnaires: the long version with 100 items which represents 25 item skills and the short version questions. In this research, we use the short version of the questionnaires developed and adapted by (Gupta, Kumar, \& Singh, 2014).

There are many definitions of job satisfaction. In general, it is defined as a pleasurable emotional state and attitude toward the job based on one's perception and adaptability of one's job (Anu, 2013). Job satisfaction represents how you feel about your job and what you think about your job.

\section{The Relationship Between Individual} Spirituality (IS) and Spirituality at Work (SAW) Research in workplace spirituality have received positive outcomes and have received empirical support from different units of analysis. At the individual level (Milliman et al., 2003) found that workplace spirituality is significantly related to attitudes such as organizational commitment, individual intention to quit, intrinsic work satisfaction, job involvement organization-based self-esteem (Rego \& Miguel Pina e, 2008). The research also found that employees' perception toward workplace spirituality is significantly related to work commitment and job performance. (Duchon \& Plowman, 2005) and on the organizational level, they further found that work unit that scored high in spirituality at work (SAW) outperformed work unit with alow score of SAW.

Nonetheless, the research reveals that potential antecedents of SAW are not common. SAW is observed mostly as an independent variable in the quantitative research. Other researchers do not use a quantitative empirical approach nor a qualitative empirical approach, but merely present a conceptual literature review focusing on the concept of workplace spirituality. This research will try to delve deeper in determining the antecedent of SAW.

Another way to seek for the antecedent of SAW, is looking at EQ as an antecedent to workplace spirituality and it is proven to be significant
(Charoensukmongkol, Daniel, \& Chatelain-Jardon, 2013). The EQ toward SAW researcher also suggested analyzing individual spirituality as a possible antecedent of spirituality at work. Spirituality in an individual (IS) further enhances EQ as cited by Wigglesworth (2013).

Charoensukmongkol et al. (2013) suggested that organizations should select employees with higher levels of EQ and that an EQ employing training program would be beneficial. (Levenson, Aldwin, \& Yancura, 2006) reported that after a year of training, the participants of EQ training were found to have a higher level of empathy, forgiveness, spiritual experience, and life satisfaction. This research further supports Wigglesworth (2013) findings, which suggests that Individual Spirituality is an enhancement after a mature person exercises their EQ. The conversation on spiritual intelligence opens up a new way to talk about developing human capacity in the spiritual skills based. Spiritual before was a beliefs problem. Beliefs remain a private matter, but spiritual intelligence can be taught (Wigglesworth, 2013).

Since Emotional Quotient is proven to be the antecedent of Workplace Spirituality, we would want to evaluate EQ plus spirituality which is the Spiritual Quotient which can be seen through individual spirituality (IS) as the antecedents of spirituality in the workplace (SAW). Rojas (2013) had developed an independent assessment which has a more extensive approach to measuring individual spirituality. Rojas instrument is used because of its special approach of measuring spirituality regardless of denomination, religious or ideological preference (Rojas, ProQuest, Learning, \& Argosy, 2002). This individual spirituality which reflects the spiritual intelligence arguably would support the employees in experiencing spirituality in the workplace.

\section{The Relationship Between Spirit at Work (SAW) and Organizational Commitment (OC)}

wrote that spirituality and management though once incompatible, are now positively correlated. People argued that spiritual being a nonmaterialistic concern is incompatible with the 
material gains to be reaped in an efficient and effective functioning of organizations. Against all odds, more and more researcher supports the premises that the more people devote to the higher cause, the more they are contributing to the organizational performance. Researchers agree to the appeal of spirituality, for several reasons:

- Organizations are a great human achievement since work is the centerpiece of most people's lives, it should be part of people's search for the ultimate meaning (Mitroff, 2003).

- Spirituality enhances employee well-being and quality of life, it provides employees a sense of purpose and meaning of work, spirituality provide employees a sense of interconnectedness and community (Karakas, 2011).

- Meaning in work, the community at work and positive organizational purpose were positively related to job satisfaction and organizational commitment (Piryaei \& Zare, 2013).

- If inappropriately managed, workplace spirituality may imbue organizational structures with spiritual aspect that serves as a new technology of control, a form of domination in a more sophisticated form (D'Oliveira, Rego, \& e Cunha, 2006)

- If correctly interpreted, workplace opportunities to perform meaningful work in the context of a community with a sense of joy and personal fulfillment will mitigate or remove what several authors have pointed as allegedly present in many modern organizations: Injuries to employees' mental health, people humiliation and destruction, dehumanized practices with threats to the human soul (Mitroff, 2003).

Organizational Commitment is a popular construct to determine the degree of moral obligation and commitment of a person to their company. One of the most cited constructs of organizational commitment is proposed by Allen and Meyer (2003) as a measurement of employees' commitment. There are three different commitment, namely affective, normative and continuance.

Workplace spirituality strives, despite the controversy and skepticism among researchers. In this research, we will conduct more thorough research on the implementation of workplace spirituality and its impact toward organizational commitment. The organizational commitment comprises of three different considerations: affective commitment (emotional attachment to the organization), normative (feelings of obligation towards the organization) and continuance commitment (perceived costs associated with leaving the organization). The stronger the organizational commitment, the stronger the intent to stay in the company.

Since there are three different reasons for staying in the organizations, each of the organizational commitment has its own value. The highest is the affective commitment, which will lead to lower turnover, improved performance. The normative commitment will not come up with such a high performance since they are doing the job because of the norm, not because of pure willingness as in the case of affective commitment. The third commitment, continuance is because they are better off in the current position, thus they are grateful that they are currently already in the best place to work even when they do not necessarily have better alternatives.

\section{The Relationship Between Spiritual at Work (SAW) Toward Job Satisfaction (JS)}

There is only limited research in regard to a study on workplace spirituality on how it impacted Job Satisfaction. Gupta (2014) conducted an empirical research on spirituality in the workplace and how it influenced the job satisfaction. There is significant evidence based on the statistical empirical research that spirituality in the workplace has a very significant impact toward job satisfaction. Other research conducted by Giacalone et. al empirically tested the relation between organizational spirituality with job satisfaction, organizational frustration and other job and organizational identification. These findings 
show that organizational spirituality is positively related to job involvement, organizational identification, and work rewards satisfaction and negatively related to organizational frustration (Giacalone \& Kolodinsky, 2008). More recently, Piryaei and Zare conducted research on workplace spirituality and positive work attitudes: The moderating role of individual spirituality. They came up with the result that workplace spirituality was positively related to job satisfaction (Piryaei \& Zare, 2013).

\section{Research Model and Hypotheses Development}

Based on the above-mentioned theory and literature exploration, the researcher sets up a research model with the main research questions on how individual spirituality impact workplace spirituality and how it influences the organizational commitment and job satisfaction. The followings are the Research model and the hypotheses:

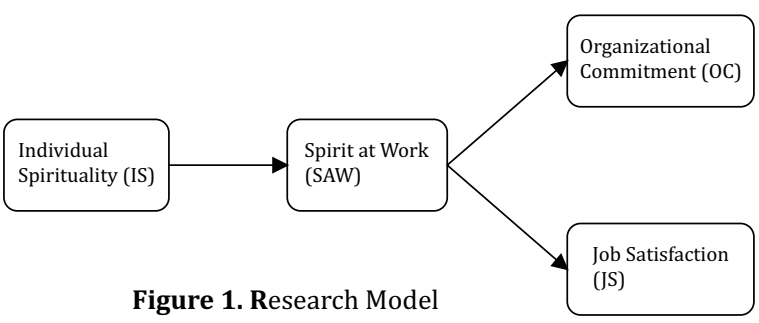

H1: The higher the level of Individual Spirituality (IS), the higher the level of Spirituality at Work (SAW).

H2: The higher the level of Spirituality at Work (SAW), the higher the level of Organizational Commitment (OC)

H3: The higher the level of Spirituality at Work (SAW), the higher the level of Job Satisfaction (JS)

\section{METHODOLOGY}

A pool of indicators used in several studies is adopted for this research. All items are measured using a 5-point Likert scales, ranging from strongly disagree to strongly agree.

To measure the individual spirituality (IS), instruments and indicators established by Ronald Raymond Rojas were used. It encompasses 13 dimensions of namely: Fulfillment of Self, Self
Determination, Self-Control, Discovery of Self, Enrichment of Self, Partnership mode, Small group Mode, Organizational Mode, Movement mode, Ideopraxis (congruence of ideology and lifestyle), transactional mode, transformational mode and Transfigurational mode. Each of the dimensions has 3 indicators.

Spiritual at work is measured by the dimensions of Kinjerski (2013), namely: Engaging Work, Mystical Experience, Spiritual Connection and Sense of Community. This dimensions and indicators of organizational commitment are measured through the adaptation of organizational commitment dimensions by (Allen \& Meyer, 1990).

Job satisfaction is measured by the indicators adapted from the Minnesota Satisfaction short version Questionnaire (Gupta etal., 2014).

PT. Telkom Indonesia has a highly selected platinum level regional operational office called Witel Telkom (Wilayah telekomunikasi). There is only eight high level "platinum" qualification of Witel in Indonesia. Platinum level is given to Witel which is categorized as the highest revenue generator. The best performing Witel is The Central Jakarta Telecom, receiving the award as the highest quality regional telecom in Indonesia. We use 31 samples from Witel Central Jakarta Telecom. All of the respondents are male, from officer up to manager level. Respondents are at the minimum officers, to ensure that the respondents have adequate experience and knowledge to respond to the questionnaire.

\section{FINDINGS AND DISCUSSION}

Personally administered surveys were used to collect data from respondents. The response rate is high 91.2 percent. Thirty-one out of 34 respondents returned the completed survey. Due to the limited sample size, the hypotheses were tested using partial least square, PLS (Ghozali 2008, Hair et al. 2006).

Statistical findings suggest that Individual Spirituality influence Spiritual at Work positively. And the finding also shows that Spiritual at Work 
Table 1. Reliability Analysis

\begin{tabular}{|c|c|c|}
\hline Scale name & $\begin{array}{l}\text { Number } \\
\text { of items }\end{array}$ & $\begin{array}{l}\text { Cronbach's } \\
\text { Alpha }\end{array}$ \\
\hline \multicolumn{3}{|l|}{ A. Individual spirituality } \\
\hline Fulfillment of Self & 3 & 0.663 \\
\hline Self Determination & 3 & 0.883 \\
\hline Self-Control & 3 & 0.521 \\
\hline Discovery Self & 3 & 0.697 \\
\hline Enrichment of Self & 3 & 0.781 \\
\hline Partnership mode & 2 & 0.549 \\
\hline Small Group Mode & 3 & 0.881 \\
\hline Organizational Mode & 3 & 0.849 \\
\hline Movement Mode & 2 & 0.568 \\
\hline Ideopraxis & 2 & 0.5 \\
\hline Transformational Mode & 3 & 0.632 \\
\hline Transfigurational Mode & 3 & 0.631 \\
\hline \multicolumn{3}{|l|}{ A. Individual spirituality } \\
\hline Engaging & 7 & 0.944 \\
\hline Mystical experience & 4 & 0.894 \\
\hline Spiritual & 3 & 0.850 \\
\hline Sense & 3 & 0.812 \\
\hline \multicolumn{3}{|l|}{ A. Individual spirituality } \\
\hline Affective & 3 & 0.922 \\
\hline Continuance & 5 & 0.961 \\
\hline
\end{tabular}

Table 3. R Square Result

\begin{tabular}{|l|c|}
\hline & JR Square \\
\hline Job Satisfaction (JS) & 0,549 \\
\hline Organizational Commitment (OC) & 0,268 \\
\hline Spirit at Work (SW) & 0,682 \\
\hline
\end{tabular}

matters, in enhancing Organizational Commitment and Job Satisfaction.

\section{MANAGERIAL IMPLICATIONS}

The current study was designed to demonstrate the impact of Individual Spirituality as a significant antecedent of workplace spirituality which gives significant impact toward organizational commitment and job satisfaction. The Great Spirit Grand Strategy approach by PT. Telkom is doing a great approach by nurturing the employees' spirituality based on their respective religion. The spiritual division encourages every employee to be more pious, as a Moslem, a Christian or any other religion in Indonesia. The spiritual division was established since January 2013, to date, there are 6774 employees (Spiritual Capital division data as of Sept 2014: Islam 5829, Christian 617, Hindu 328) who have been going through an intensive spiritual at work training for four to five days, based on their respective religion. In estimation by the end of the fourth quarter, there will be 9000 graduates of spiritual at work training which is $52 \%$ of the total employees.

The implications of the research supported the importance of the continuous program to improve individual spirituality. In addition to the one full week training of spiritual at work, Telkom has a nation-wide program of Spiritual Enhancement every week. The spiritual division has specifically designed a curriculum for a weekly short version of the spiritual talk. All Telkom offices in Indonesia will have the exact same program available for every religion (Islam, Christian, Catholic, Hindu, and Buddhism) to serve as a spiritual booster to the employees. This research has proven that Spirituality at Work matters in the Strategic Management concept, and belonging to a certain support group is one of the important aspects to support an individual to maintain their spirituality as a human being by always offering the best service in the workplace.

\section{CONCLUSION, LIMITATION, AND SUGGESTIONS FOR FURTHER RESEARCH}

This research has supported that Individual Spirituality is positively and significantly impacting the experience of spirit at work and influencing significantly Organizational Commitment and Job Satisfaction. The individual intangible capabilities are in the form of Individual Spirituality, where individuals are seen through their quality in feeling fulfilled, the level of self-determination, selfcontrol, self-discovery, and self-enrichment.

Table 2. Statistical Evaluation Result

\begin{tabular}{|l|l|l|l|l|l|}
\hline Independent & dependent & T-Value & Loading & p-Value & Conclusion \\
\hline IS & SAW & 2,961 & 0,597 & 0,003 & Significant \\
\hline SAW & JS & 10,310 & 0,741 & 0,000 & Significant \\
\hline SAW & OC & 10,310 & 0,518 & 0,000 & Significant \\
\hline
\end{tabular}


Individual spirituality is also seen from their role in the partnership, small group, organizational and movement.

The limitation of this research lies in the limited amount of respondent with samples only from one Witel, which implies that the result refers to the case of Witel Telkom of Central Jakarta. Based on secondary data, the trend in PT Telkom shows an improvement in their overall performance since the first time they have conducted the great spirit grand strategy approach. Therefore, a longitudinal future research needs to be conducted to see the long-term impact of the great spirit grand strategy approach. A more elaborate quantitative research and exploratory approach to the influence of spirituality at work toward sustainable mindset implementation will make a good additional emphasis on the importance of spirituality in the workplace.

In the future, it will also be interesting to see the difference of this model when implemented in a different type of companies, i.e: Service industry versus Manufacturing industry. For future work, it will also be important to see further the impact of different cultural characteristics of the individual and how it is influencing Spirit at Work. The impact of various cultures on this construct can be seen through Western culture versus Eastern culture.

\section{REF E REN CES}

Allen, N. J., \& Meyer, J. P. (1990). The measurement and antecedents of affective, continuance and normative commitment to the organization. Journal of occupational psychology, 63(1), 1-18.

Anu, D. (2013). Spirituality at Workplace and Job Satisfaction. International Journal of Biosciences, Alternative and Holistic Medicine, 4(1), 1-9.

Arménio, R., \& Miguel Pina e, C. (2008). Workplace spirituality and organizational commitment: an empirical study.Journal of Organizational Change Management, 21(1), 53-75.

Benefiel, M. (2003). Mapping the terrain of spirituality in organizations research. Journal of Organizational Change Management, 16(4), 367-377.

Charoensukmongkol, P., Daniel, J. L., \& Chatelain-Jardon, R. (2013). Enhancing Workplace Spirituality Through Emotional Intelligence.Journal of Applied Management and Entrepreneurship, 18(4), 3.

Chen, J.-C., Silverthorne, C., \& Hung, J.-Y. (2006). Organization communication, job stress, organizational commitment, and job performance of accounting professionals in Taiwan and America. Leadership \& Organization DevelopmentJournal, 27(4),242-249. doi:10.1108/01437730610666000

D'Oliveira, T., Rego, A., \& e Cunha, M. P. (2006). Organizational Spiritualities: An Ideology-Based Typology. Business \& Society, 45(2), 211-234. doi:10.1177/0007650306286737

Duchon, D., \& Plowman, D. A. (2005). Nurturing the spirit at work: Impact on work unit performance. The leadership quarterly, 16(5),807-833. doi:10.1016/j.leaqua.2005.07.008

Giacalone, R. A., \& Kolodinsky, R. W. (2008). Workplace values and outcomes: exploring personal, organizational, and interactive workplace spirituality. Journal of Business Ethics, 81(2), 465-480. doi:10.1007/s10551-007-9507-0

Grunberg, L., Anderson-Connolly, R., \& Greenberg, E. S. (2000). Surviving Layoffs: The Effects on Organizational Commitment and Job Performance. Work and Occupations, 27(1), 7-31. doi:10.1177/0730888400027001002

Gupta, M., Kumar, V., \& Singh, M. (2014). Creating Satisfied Employees Through Workplace Spirituality: A Study of the Private Insurance Sector in Punjab (India). Journal of Business Ethics, 122(1), 79-88. doi:10.1007/s10551-013-1756-5 
Hayati, K., \& Caniago, I. (2012). Islamic Work Ethic: The Role of Intrinsic Motivation, Job Satisfaction, Organizational Commitment and Job Performance. Procedia - Social and Behavioral Sciences, 65(Journal Article), 272-277. doi:10.1016/j.sbspro.2012.11.122

Kinjerski, V. (2013). The Sprit at Work Scale: Developing and Validating a Measure of Individual Spirituality at Work.

Kinjerski, V. M., \& Skrypnek, B. J. (2004). Defining spirit at work: finding common ground. Journal of Organizational Change Management, 17(1), 26-42. doi:10.1108/09534810410511288

Levenson, M. R., Aldwin, C. M., \& Yancura, L. (2006). Positive emotional change: mediating effects of forgiveness and spirituality. Explore (New York, N.Y.), 2(6), 498-508. doi:10.1016/j.explore.2006.08.002

Memari, N., Mahdieh, O., \& Marnani, A. B. (2013). The impact of Organizational Commitment on Employees Job Performance. "A study of Meli bank". Interdisciplinary Journal of Contemporary Research In Business, 5(5), 164.

Meyer, J. P., \& Parfyonova, N. M. (2010). Normative commitment in the workplace: A theoretical analysis and re-conceptualization. Human resource management review, 20(4), 283-294. doi:10.1016/j.hrmr.2009.09.001

Milliman, J., Czaplewski, A. J., \& Ferguson, J. (2003). Workplace spirituality and employee work attitudes: An exploratory empirical assessment. Journal of Organizational Change Management, 16(4), 426-447. doi:10.1108/09534810310484172

Mitroff, I. I. (2003). Do Not Promote Religion Under the Guise of Spirituality. Organization, 10(2), 375-382. doi:10.1177/1350508403010002011

Mitroff, I. I., \& Denton, E. A. (1999). A spiritual audit of corporate America: a hard look at spirituality, religion, and values in the workplace: Jossey-Bass Publishers.

Peerayuth, C., Jose Luis, D., \& Ruth, C.-J. (2013). Enhancing Workplace Spirituality Through Emotional Intelligence.Journal of Applied Managementand Entrepreneurship, 18(4), 3.

Piryaei, S., \& Zare, R. (2013). Workplace spirituality and Positive Work Attitudes: The moderating role of Individual Sprituality. Indian Journal of Economics and Development, 1(4).

Rego, A., \& Miguel Pina e, C. (2008). Workplace spirituality and organizational commitment: an empirical study. Journal of Organizational Change Management, 21(1), 53-75. doi:10.1108/09534810810847039

Riketta, M. (2002). Attitudinal organizational commitment and job performance: a meta-analysis. Journal of organizational behavior, 23(3), 257-266. doi:10.1002/job.141

Rojas, R. R., ProQuest, I., Learning, C., \& Argosy, U. S. (2002). Management theory and spirituality: a framework and validation of the Independent Spirituality Assessment Scale. (Dissertation/Thesis), ProQuest, UMI Dissertations Publishing.

Samad, S. (2005). Unraveling the Organizational Commitment and Job Performance Relationship: Exploring the Moderating Effect of Job Satisfaction. The Business Review, Cambridge, 4(2), 79.

Wigglesworth, C. (2013). Spiritual Intelligence. Springer Science.

Wright, T. A. (1997). Job Performance and Organizational Commitment. Perceptual and motor skills, 85(2), 447-450. doi:10.2466/pms.1997.85.2.447 